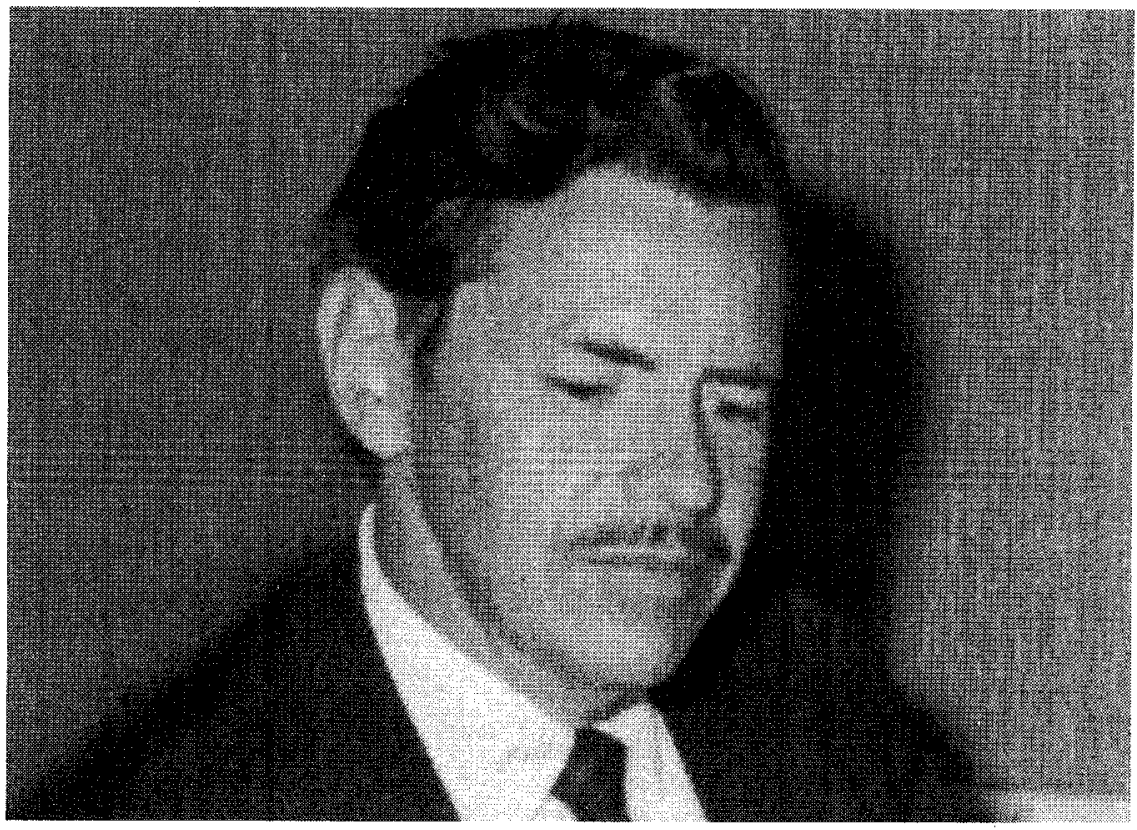

\title{
In Memoriam: Professor William Arthur Kelly
}

Editor's Note: Professor William Arthur Kelly, 84, died July 12, 2006. His longtime colleague and friend Professor Robert Casad graciously agreed to pen this tribute.

Our colleague and friend Bill Kelly passed away July 12, 2006, his 84th year. His contributions to our law school were many and important. He will be missed but not forgotten.

Bill was KU through and through. He received his A.B. degree in political science in 1942, and was elected to Phi Beta Kappa. After serving with distinction as a decorated infantry officer in Europe during World War II, he enrolled in this law school in 1947. An outstanding student, he was elected to the Order of the Coif upon graduation in 1949.

After eight years of law practice in Kansas City, Missouri, he came to our faculty as an Associate Professor in the fall of 1957. He was immediately popular as a teacher. During the 1961-1962 academic year Bill served as Acting Dean of the law school, a role he assumed again in the Spring Semester of 1966. At that time we had only one Associate Dean, and Bill was it from 1962 to 1969 , a period that saw a great expansion of the school's programs, faculty, student body, and alumni support. 
Bill was a very good liaison between the law school and its alumni, and he figured prominently in the establishment and ongoing activities of the KU Law Society. In 1992, he was honored by that Society as the Distinguished Alumnus of the KU School of Law.

From 1969 to 1975 Bill was one of Kansas's three Commissioners in the National Conference of Commissioners of Uniform State Laws. Beginning in 1963, he was a member of the Board of Editors of the Kansas Bar Journal, a post he held for many years.

Bill was a very good speaker and actor and appeared in several of the productions of the Lawrence Community Theater. He was one of the original members of KANU's "Imagination Workshops." For many years, he was a volunteer reader for the Audio Reader. It was Bill who narrated the video about the KU Law School, produced in 1993 to honor the school's centennial celebration.

Upon retirement from active teaching in the law school, Bill remained very active in the KU Retirees Club, serving a term as president of that group.

On top of all his service activities to the law school, the university, the state, and the Lawrence community, Bill was very devoted to his family. $\mathrm{He}$ and his wife Caroline (who insisted on being called Kay by everyone except Bill) raised a family of five talented children who were the light of his life. Bill and Kay were married for 51 years before her death in 1994. Later he married Patricia (Pat) Collison who survived him, along with his five children: Billie, Mike, Tim, Shawn, and Kevin.

We mourn the loss of our friend and colleague, but we, his colleagues, and the entire law school, are richer because he was here.

Robert C. Casad

John H. and John M. Kane Professor of Law

Emeritus 